\title{
A review of the use of probiotics in freshwater prawn (Macrobrachium sp.) culture in biofloc systems
}

\author{
Kathia Cienfuegos-Martínez ${ }^{1}$, María del Carmen Monroy-Dosta ${ }^{2}$, Aida Hamdan-Partida ${ }^{3}$ \\ Martha Patricia Hernández-Vergara ${ }^{4}$, Daniel Becerril-Cortés ${ }^{1}$ \& Evelyn López-García ${ }^{2}$ \\ ${ }^{1}$ Doctorado en Ciencias Biológicas y de la Salud, Universidad Autónoma Metropolitana \\ Unidad Xochimilco, Ciudad de México, México \\ ${ }^{2}$ Departamento del Hombre y su Ambiente, Universidad Autónoma Metropolitana \\ Unidad Xochimilco, Ciudad de México, México \\ ${ }^{3}$ Departamento de Atención a la Salud, Universidad Autónoma Metropolitana \\ Unidad Xochimilco, Ciudad de México, México \\ ${ }^{4}$ Laboratorio de Cultivo y Nutrición de Crustáceos, Instituto Tecnológico de Boca del Río \\ Veracruz, México \\ Corresponding author: María del Carmen Monroy-Dosta (monroydosta@hotmail.com)
}

\begin{abstract}
This document is an updated review on the use of probiotics to the freshwater prawn Macrobrachium sp. culture in biofloc systems, pointing out the benefits in growth, survival, improvements in the immune system, pathogen control, and water quality. The review also emphasizes some aspects that need to be defined with greater accuracy, like the effect of doses and times of probiotic administration and refers to bacterial dynamics associated with biofloc. This review aims to enhance the knowledge of probiotics in commercially important species such as the freshwater prawn.
\end{abstract}

Keywords: Macrobrachium sp.; shrimp; probiotics, bacteria; biofloc system; water quality exchange; aquaculture

\section{INTRODUCTION}

Microbial communities in the aquatic habitat respond quickly to the changes in their environment. The changes can be subtle and manifest as activation or inactivation of the bacterial community's specific metabolic pathways or as changes in its composition, structure, and functionality, also called microbial loop (Bentzon et al., 2016). The same happens in aquaculture production systems where the products generated in closed systems and under a continuous flow of water are diverse and can act positively in transforming the organic matter and the compounds generated in the production systems. At the same time, these products are used as a source of microbial biomass available for larger organisms. Still, they also exert detrimental effects and can develop virulence factors in response to environmental variations (De Schryver et al., 2008). Recent studies suggest that proper management of microbial communities can help obtain better water quality, increase nutrient levels, and reduce pathogenic bacteria, thereby increasing the survival of the cultured species without using chemical substances or antimicrobials. Currently, in aquaculture, there are several concerns regarding the use of specific systems. Among these concerns are such as diseases in cultured animals, constant changes in water quality, and constant changes in the microbial community that can represent an input vector for pathogenic microorganisms. Also, these water changes lead to de indiscriminate use of this resource is made, which is limited throughout the world. Besides, discharge of this culture water leads to the contamination of water bodies, i.e., lakes, rivers, seas, and oceans, because it contains feces, dead animals, hormones, antibiotics, pathogenic microorganisms, among others. Therefore, it is required to implement the use of technologies or systems that will allow avoiding these noxious effects on both animals and the environment (Prindle et al., 2012; Bentzon et al., 2016). One of the most used tech-

Corresponding editor: Eduardo Ballester 
nologies in aquaculture for manipulating microbiota in culture systems is the application of probiotics, like Bacillus and Lactobacillus (Pandiyan et al., 2013) showing benefits for animal health and water quality throughout different action mechanisms, immune response stimulation, segregation of substances that inhibit the growth of pathogenic microorganisms, enzyme production that induces absorption and improves the nutrition of fish and crustaceans, and reduction of compounds derived from the microbial metabolism (Yamashita et al., 2016; Das et al., 2017). Likewise, in the last years, the search for new sustainable aquaculture technologies has allowed the development of cultures in biofloc systems. Microbial oxidant reduction processes are carried out by the addition of a carbon source (Ferreira et al., 2015), allowing zooplankton promotion. It can serve as food for the cultured species, with a positive effect on water quality and control of pathogens without the need of chemicals and antibiotics and, as a consequence, less environmental impact (Ahmad et al., 2017).

\section{Freshwater prawn importance}

The Macrobrachium genus is composed of 238 species distributed from the tropical and subtropical fringe around the world to temperate regions (Bauer, 2011). In this genus, significant variations occur in terms of length, morphology, and habitat requirements (Pileggi \& Mantelatto, 2010).

The larvae that belong to this genus are planktonic, and, once they pass to the juvenile stage, they begin to migrate from the coast to the deeper areas of freshwater, contributing to the energy flow that later becomes biomass along with the different habitats through which they transit. This characteristic is known as amphidromy (McDowall, 2007). It places the prawns in a prominent position in the list of adaptations and ecological roles present in aquatic organisms, even from an evolutionary perspective.

Freshwater prawns are a group of aquatic animals that have an important ecological role for the environmental dynamics of the ecosystems of rivers and lagoons (Murphy \& Austin, 2005). They are considered omnivores and scavengers; furthermore, they consume algae, remains of dead animals, and detritus (Albertoni et al., 2003). Some species of the genus Macrobrachium have a high economic value due to their high protein content, good taste, and visual appeal, making it a well-priced product as food for human consumption (García-Guerrero et al., 2013).

\section{Difficulties in the culture}

One of the central concerns in the culture of organisms such as tilapia, shrimp, and prawn (Macrobrachium sp.) is the intensive intervention during their production practices, which degrade the environment. First, the use of water produces enormous amounts of waste, such as not consumed food, excretion products, chemicals, even microorganisms, and parasites; second, because antibiotics and chemical substances are introduced into the ecosystem, which is necessary to carry out the activity. This impact has environmental, economic, and social costs (Buschmann, 2007).

For the production of aquatic organisms, including prawns, it is necessary to use water, even for small to medium systems that can reach up to several hundred cubic meters per day, so that water becomes a limiting factor for the activity (Borja, 2002). Also, diseases are a risk faced by prawns during their culture because they are vulnerable and under stress conditions. Among them are those caused by Vibrio species, which cause mortality of the organisms and, consequently, economic losses; for these reasons, technologies that solve these problems have been chosen (Ajadi et al., 2019).

\section{Biofloc system}

Biofloc technology (BFT) is a culture system consisting of microbial flocs made up of microorganisms, such as rotifers, nematodes, copepods, bacteria, and zooplankton. This technology is based on a minimum or zeroes replacement of water, which allows having fewer adverse effects on the environment, and, as an additional benefit, microbial protein is produced in the system that can be used as food by the organisms. According to Emerenciano et al. (2011), this technology was developed in the 70s by IFREMERCOP (French Research Institute for Exploitation of the Sea, Oceanic Center of Pacific) with different aquatic species such as Penaeus monodon, P. vannamei, Fenneropenaeus merguiensis, among others.

The flocs are formed by adding carbon sources to the water body. For the formation of flocs, an external carbon source is required at a 20:1 ratio of C:N to be added to the water, this can be achieved with molasses, rice flour, coffee, moringa, or tapioca, among others. The microorganisms that develop in this system have two main functions: 1) to maintain water quality by transforming toxic nitrogen into microbial protein, and 2) to serve as a natural food source for animals in culture (Emerenciano et al., 2013).

The microbial communities that make up the biofloc are developed by populations of cells of various species, which interact with each other by carrying out multiple functional activities within the community and with their host (Díaz \& Wacher, 2003). In recent years, in the aquaculture of some crustaceans and fish, microbial consortia have been used as a food source and to improve the culture environment (Becerra et al., 2014). 
One of the studies, Deng et al. (2018), describes the biofloc microbiota. They evaluated the effect of the addition of tapioca starch, cellulose, and their combination, on the microbial diversity of the biofloc, during the cultivation of the herbivorous carp through mass sequencing, reported that regardless of the source of carbon added to the culture system, the Proteobacteria, and Bacteroidetes phyla were the most abundant. It should be noted that the bacteria belonging to these phyla are reported in different studies as ubiquitous in aquatic environments and aquaculture production systems (Guo et al., 2011; Wei et al., 2016; Zhou et al., 2017).

On the other hand, it has been shown that Proteobacteria, which are commonly found in biofloc systems, is a microbial group in charge of nutrient recycling and mineralization of organic components in aquatic systems (Cardona et al., 2016). Martins et al. (2013) indicate that the Proteobacteria group comprises several phototrophic and heterotrophic genera with a high degradative capacity of compounds such as methane and methanol in aquatic environments. Deng et al. (2018) mention that Betaproteobacteria, also commonly found in biofloc, is a group of aerobic or facultative bacteria responsible for transforming nitrogen compounds in aquatic ecosystems, the most important belong to the Nitrosomonas genus, which oxidizes ammonia. Moreover, bacteria such as Pseudomonadaceae (Ndi \& Barton, 2012), Caulobacteraceae (Guo et al., 2011), Chitinophagaceae (Bartelme et al., 2017), and Sphingobacteriaceae (Bartie et al., 2005), are efficient in the transformation of various compounds generated during cultivation within the water column (cellulose, chitin, collagen, and nitrogen), thus promoting the use of products that otherwise could be considered pollutants.

Despite the relevance of bacteria in the functioning of the digestive tract in aquatic species, there are few investigations aimed at identifying microbial species that develop in the water and the intestine of the species in cultivation. In this regard, through an extensive sequencing study, Tzeng et al. (2015) determined that the main bacterial phylum in the intestine of Macrobrachium nipponense was that of Proteobacteria, followed by Firmicutes and Actinobacteria.

Chen et al. (2017) observed, through the technique of massive sequencing in water and the intestine of Macrobrachium nipponense, that changes in the environment can influence the intestinal microbiota, not only by providing microorganisms associated directly with the environment but also by indirectly interfering with the composition of established intestinal bacteria. Pérez-Fuentes et al. (2016) observed the development of different bacteria through the 16S gene of rRNA, in tilapia (Oreochromis niloticus) cultured in a biofloc system, in both the intestine and water, and found that the main pathogenic bacteria in water were: Aeromonas hydrophila, A. salmonicida, Escherichia coli, Vibrio fluvialis, and non-pathogens: Bacillus subtilis, Enterobacter sp., Micrococcus sp., they also observed that by decreasing the amount of food supplied to the fish, the number of recorded bacteria increased. In the intestine of the tilapia, they recorded 15 species of pathogenic bacteria (among them Aeromonas hydrophila, A. sobria, E. coli, Pseudomonas cepacia) and non-pathogenic (Bacillus pumilus, B. subtilis, Micrococcus sp.).

Although some studies have identified and classified the microbiota present in the biofloc during the culture of different prawn and shrimp species, research is still needed on the microbial communities that develop in both the water and intestine in the biofloc system during shrimp farming.

On the other hand, in recent years, research has been carried out to cultivate prawn ( $M$. nipponense) in biofloc systems, due to the different benefits offered by this technology (Emerenciano et al., 2017). Among these benefits are greater growth and survival in cultured animals, a decrease in commercial food investment, improvement in water quality, and fewer water refills. Ballester et al. (2017) cultivated prawns $(M$. rosenbergii) with two treatments, a biofilter recirculation system (RAS) and another with microbial flocs (F). Resulting in the high density of rotifers, ciliates, and flagellate, as well as bacteria, these were identified in treatment $\mathrm{F}$, and attributed to the source of carbon used; because the carbon source promotes an increase in bacterial biomass, which, in turn, stimulates the development of other microorganisms, and these will be used as natural food in situ by cultured animals.

Another benefit of biofloc systems is pathogen exclusion, which is very important because, in aquaculture systems, infectious diseases caused by pathogen microorganisms are responsible for substantial economic losses, as they can cause mortalities higher than $90 \%$. A strategy to reduce the diseases' impact is the use of antibiotics because they help to control some bacterial infections. However, there are many problems associated with their use. The inappropriate application of antibiotics has led to the development of resistance to them by bacteria; consequently, there is an urgent need for alternative sustainable control techniques (Kathleen et al., 2016).

Biofloc technology applied to aquaculture is a tool for pathogen control in the aquatic environment. In contrast to conventional approaches, it does not generate resistance to pathogens. Its action derives from a competitive exclusion effect by probiotic 
bacteria against other microbial groups, by secreting a wide variety of exoenzymes and polymers that generate an environment hostile to bacteria, especially to pathogens (Monroy et al., 2015). The probiotic potential of the biofloc maybe since part of the intestinal microbiota of aquatic organisms is released through the feces to the environment, which, due to its nature, has high nutrient loads, allowing for their proliferation. The cultivated species take advantage of the benefits provided by these microorganisms (Crab et al., 2010). In this regard, Maya et al. (2016) identified bacteria of the Bacillus, Lactobacillus, Lactococcus, Saccharomyces genera known for their probiotic potential in a biofloc system, which indicates that, in the biofloc, various genera of probiotics are developed that provide benefits to both animals and culture water.

The presence of natural probiotics in biofloc culture systems reduces water treatment costs by up to $30 \%$ since this system can operate with a low water exchange, with rates of 0.5 to $1 \%$ per day. At the same time, aeration is maintained at $4.0 \mathrm{mg} \mathrm{L}^{-1}$ to keep flocs suspended (Crab et al., 2009).

The water quality in a biofloc system is regulated by the bacterial community and its development from the carbon-nitrogen relationship, which guarantees the proliferation of heterotrophic bacteria that transform nitrogen compounds, such as ammonia, into simpler compounds that are not harmful to animals in culture (Samocha et al., 2007; Asaduzzaman et al., 2010). Biofloc systems are complex ecosystems subjected to various biochemical processes that vary relative to the conditions in which the culture develops and is dependent on water quality values (Table 1).

In recent decades, the massive expansion of aquaculture has begun to face some important limitations, such as the increase in demand and price of fishmeal, which is the primary raw material for the preparation of aquaculture diets. However, due to overfishing, natural populations are unable to meet the demand. Aquaculture needs to obtain alternative protein sources to replace the use of fishmeal (Avnimelech, 2012; Crab et al., 2012).

Biofloc cultures are a technological alternative to optimize the use of aquaculture diets, leading to the reduction of fishmeal inclusion in the formulations. In this type of systems, a wide range of microorganisms (bacteria, phytoplankton) is developed, as well as organic matter aggregates, in addition to rotifers, ciliates, protozoa, and copepods that form macroaggregates (biofloc) a rich natural source of protein: lipid "in situ" available $24 \mathrm{~h}$ a day for organisms in culture. It is known that the potential feed gain with this technology is 10 to $20 \%$, with the consequent 40 to $50 \%$ reduction in feed costs (Azim \& Little, 2008; Poleo et al., 2011; Hargreaves, 2013); furthermore, the biofloc has a protein content of between 25 and $50 \%$ and the fat content ranges from 0.5 to $15 \%$ (Emerenciano et al., 2013).

\section{Probiotics: definition and benefits}

This term was used for the first time in 1965 by Lilly \& Stillwell as a modification of the original word "probiotika." In 1989, Fuller expanded the definition to "live microbial food supplement that benefits the host (human or animal) by improving the microbial balance of the body." There are several definitions for the word "probiotics" that have been modified over time. However, a more general and shared concept of probiotic is proposed by Irianto \& Austin (2002) "one or more microorganisms with beneficial effects for the host, able to persist in the digestive tract because of its tolerance to acid and bile salts." Furthermore, a probiotic can be just one microorganism or a mix of microorganisms that present a synergistic effect potentiating the benefits (Martínez-Cruz et al., 2012).

To consider microorganisms as probiotics, they must comply with specific requirements such as: being safe for the animal, i.e., not to cause disease, they must arrive alive to the gastrointestinal tract and be able to colonize it to achieve an effective competitive exclusion. Also, it must inhibit the growth of pathogenic microorganisms, both Gram-positive and Gram-negative, by producing acids or other substances that inhibit their growth. Likewise, they must have a short reproduction time, tolerate gastric $\mathrm{pH}$ and bile salts; they must be stable when in contact with bile, acids, and enzymes, and, finally, they must be stable and viable during storage (Gutiérrez, 2013).

Some studies assessed the effect of probiotics on the growth of fish and crustaceans, among them are: Seenivasan et al. (2016), who observed the effect on survival and growth, for 60 days of three probiotics (Lactobacillus sporogenes, Bacillus subtilis, and Saccharomyces cerevisiae) given in the diet for postlarvae of $M$. rosenbergii. The results indicated that all the probiotics promoted significant growth and enzyme production (protease, amylase, and lipase) in $M$. rosenbergii, but the best was $S$. cerevisiae.

During a 240 day culture with juvenile $M$. rosenbergii prawns, Ghosh et al. (2016) observed that by providing a mixture of two commercial probiotics (Zymetin: Bacillus mesentericus, and Super PS: Rhodobacter sp. and Rhodococcus sp.) the growth and productive yield of the prawns were significantly higher $(30 \%)$ compared to the other diets (without probiotics, or with probiotics added separately), indicating that their mixture yields better results than their separate addition. (Table 2). 
Table 1. Effect of a biofloc system on the water quality in crustaceans' culture.

\begin{tabular}{|c|c|c|}
\hline $\begin{array}{l}\text { Days of the } \\
\text { experiment }\end{array}$ & Water quality results & Author \\
\hline 90 days & $\begin{array}{l}\text { Treatment with molasses induced significant differences in ammonia, } \\
\text { nitrites, nitrates, and total nitrogen in the water used for the control prawn } \\
\text { (M. rosenbergii) culture. }\end{array}$ & Miao et al. (2017) \\
\hline 30 days & $\begin{array}{l}\text { Water quality parameters (total ammonium, nitrite, and nitrate) were } \\
\text { within the optimal range when adding a carbon source to shrimps }(P \text {. } \\
\text { vannamei) culture. }\end{array}$ & Suita et al. (2015) \\
\hline 21 days & $\begin{array}{l}\text { Concentrations of TAN and } \mathrm{N}-\mathrm{NO}_{2} \text { were significantly lower }(P<0.5) \text { in } \\
\text { the biofloc system in shrimps }(P \text {. vannamei) culture than in the control. } \\
\text { A significant difference }(P<0.5) \text { was obtained in the individual final } \\
\text { weight, an increase in biomass, and a better protein conversion rate for } \\
\text { biofloc treatments compared to the control. }\end{array}$ & Luis-Villaseñor et al. (2015) \\
\hline 42 days & 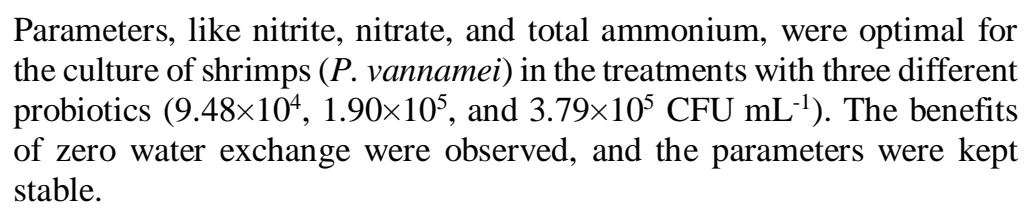 & Llario et al. (2020) \\
\hline
\end{tabular}

Table 2. Results on the significant growth of prawns by the administration of different probiotics.

\begin{tabular}{|c|c|c|c|}
\hline Probiotics & Species & Results in growth & Author \\
\hline $\begin{array}{l}\text { Bacillus subtilis and } \\
\text { Pseudomonas fluorescens }\end{array}$ & $\begin{array}{l}\text { Macrobrachium } \\
\text { malcolmsonii }\end{array}$ & $\begin{array}{l}\text { With } B . \text { subtilis, the initial weight was } \\
5.86 \mathrm{~g} \text { and final } 20.25 \mathrm{~g} \text {, and with } P \text {. } \\
\text { fluorescens, the initial weight was } 6.8 \mathrm{~g} \\
\text { and final } 18.5 \mathrm{~g} \text { after } 60 \text { days. }\end{array}$ & John et al. (2018) \\
\hline Clostridium butyricum & $\begin{array}{l}\text { Macrobrachium } \\
\text { rosenbergii }\end{array}$ & $\begin{array}{l}\text { The probiotic induced significantly higher } \\
(P<0.05) \text { weight and growth rate than in } \\
\text { the control group after } 60 \text { days. }\end{array}$ & Sumon et al. (2018) \\
\hline $\begin{array}{l}\text { Bacillus } \\
\text { Cereus }\end{array}$ & $\begin{array}{l}\text { Macrobrachium } \\
\text { rosenbergii }\end{array}$ & $\begin{array}{l}\text { The probiotic concentration }\left(1 \times 10^{4} \mathrm{CFU}\right. \\
\left.\mathrm{g}^{-1}\right) \text { induced a significantly higher growth } \\
\text { than the control group after } 28 \text { days. }\end{array}$ & Wee et al. (2018) \\
\hline $\begin{array}{l}\text { Commercial probiotic: } \\
\text { Prosol }\end{array}$ & $\begin{array}{l}\text { Macrobrachium } \\
\text { rosenbergii }\end{array}$ & $\begin{array}{l}\text { The final body weight increased, the net } \\
\text { body weight gain and the specific growth } \\
\text { rate with the probiotic was significantly } \\
\text { higher }(P<0.05) \text { after } 105 \text { days. }\end{array}$ & Gupta \& Dhawan (2011) \\
\hline
\end{tabular}

One of the most important aspects of promoting the use of probiotics in aquaculture is the water quality of the systems to which they were applied. To this regard, Akter et al. (2017) observed that when supplying commercial probiotics to the prawns (M. rosenbergii), water quality parameters (ammonium and nitrogen compounds) were in their optimal range for the species. Thus, not needing continuous water replacement for the microbial loop action since capturing the nitrogenous and transformed in less toxic compounds and generated microbial protein that will provide a supplemental source of nutrition for the animals in culture.
Rubia et al. (2017) reported that during prawn (M. rosenbergii) culture with the individual addition of three commercial probiotics, the water quality parameters remained in their optimal range without significant variations, helping the farmer to keep the water quality. Furthermore, to stabilize water quality during the culture, probiotics compete, and displace pathogenic microorganisms that cause high mortality. Mujeeb et al. (2017) detected that Brevibacillus laterosporus bacteria, isolated from a sample of $M$. rosenbergii larvae, presented antibacterial activity against pathogens, Aeromonas hydrophila and Vibrio parahaemolyticus, hence it is possible to isolate 
specific probiotics to be used on the same species. Besides, the bacterium $B$. laterosporus was also able to inhibit other bacterial genera, such as Acinetobacter, Aeromonas, Alcaligenes, Vibrio, Bacillus, Streptococcus, and Enterobacteriaceae.

Azad et al. (2019) administered the commercial probiotic Zymetin during the culture of juvenile prawns that were challenged against a pathogenic strain of Vibrio spp. and Aeromonas spp. They observed, at the end of the experiment, that there was a significant increase of total and beneficial bacterial density (Bacillus spp., Enterococcus spp., Lactobacillus spp.), and significant curtailment of some harmful bacteria (Aeromonas spp. and Vibrio spp.) in the water and prawn intestine of all tested groups $(P<0.05)$. In other words, an exclusion of pathogenic microorganisms by probiotics occurred.

Another of the main benefits of probiotics is that they stimulate the host's immune system. They act on the cells involved in natural and specific immunity (Balcázar et al., 2006); thus, probiotics have been tested in different aquatic species and varied results, although, in general, an improvement in the health or growth of organisms has been reported (Table 3 ).

\section{Probiotic concentration and dose}

Some relevant aspects of the use of probiotics are the concentration and the dose set up at which probiotics can exert the most significant possible benefit on the host. Some authors have stated the effective concentration to obtain the best results in growth, survival, as well as in the prawn's immune response. In this sense, Dash et al. (2016) evaluated the growth, food efficiency, biochemical composition, and response to three different concentrations $\left(1 \times 10^{7}, 1 \times 10^{8}, 1 \times 10^{9}\right.$

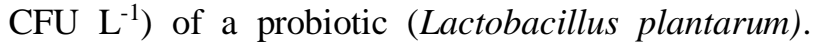
They found that they were significantly higher than in control (without probiotic).

Furthermore, Kumar et al. (2013) observed that the inclusion of a probiotic (Bacillus licheniformis) in diets led to increased growth and immune response with the highest concentration of probiotics $\left(1 \times 10^{9} \mathrm{CFU} \mathrm{\textrm {g } ^ { - 1 }}\right)$, and a significant increase of bacteria in the intestinal tract $(P<0.05)$ and the simultaneous decrease of pathogenic species, such as Aeromonas spp. and Pseudomonas spp., in all experimental groups of $M$. rosenbergii. Some investigations are described in which beneficial effects were obtained concerning growth, exclusion of pathogens, and enzymatic activity with different probiotic concentrations (Table 4).

\section{Perspectives}

In the last two decades, research on the use of probiotics in aquaculture has increased. However, there is little information about the concentration and the appropriate dose for the growth of cultured organisms and the multiple benefits they provide (Seenivasan et al., 2011; Kumar et al., 2013).

Due to the scarce research to this regard, it is necessary to face this topic specifically with a clear view of the dose to be used and the risks involved in specific objectives of the studies. On the other side, the increase in the quality and quantity of the national aquaculture production implies an improvement in the production processes involving environmental, social, and economic aspects, that is, the sustainable development of the activity (Grealis et al., 2017). In this sense, the development and implementation of probiotics in the world and Mexico, is a reality and represent one of the best options to improve aquaculture production (Cienfuegos et al., 2017). However, the functionality and, thus, the safety of this biotechnology involve research and responsible application. In Mexico, there is no regulatory framework for this biotechnology; however, there is the Official Mexican Standard NOM-061-ZOO-1999, which states that: "in the case of probiotic additives, prepared with microorganisms producing lactic acid or similar, prior previous to their regulation, you must ensure its verification to determine the genus and species used, as well as specify the concentration of viable microorganisms expressed in colony-forming units per milliliter $\left(\mathrm{CFU} \mathrm{mL} \mathrm{mL}^{-1}\right)$ or gram of finished product". As this is the only item specified for the management of probiotics in Mexico, there is much work to do for the probiotic additives in the field of aquaculture regulations to ensure their proper use. It must be emphasized that, in the first instance, it refers to the processes involved in the probiotics' development and application, that is, guidelines for their importation and evaluation of their functionality. The fact of not having adequate regulations generates misinformation and an erroneous conception of this biotechnology scope. For example, in some products available in the market, no information is given about storage, dosing, and shelf life, which can, consequently, cause a decrease in their functionality.

On the other hand, in recent decades, there has been a growing interest in the development of sustainable biotechnologies and, therefore, in the use of probiotics, which for aquaculture represents a tool that has gained relevance internationally (Pandiyan et al., 2013). However, the benefits obtained from these microorganisms, the specific aspects of the mechanisms of action by which these bacteria (mainly) exert their positive effects are still unknown. In this regard, the main lines of research have been associated with the control and prevention of pathogens, growth, digestive 
Table 3. Benefits obtained in the immune system by adding probiotics to prawn and shrimp culture.

\begin{tabular}{|c|c|c|}
\hline Microorganism used & Results obtained & Author \\
\hline Bacillus amyloliquefaciens & $\begin{array}{l}\text { With the probiotic, a higher significant stimulation of } \\
\text { the immune response of shrimps Penaeus vannamei } \\
\text { (total protein concentration, } 128 \mathrm{mg} \mathrm{mL}^{-1} \text {; cell } \\
\text { number with apoptosis, } 1 \text {; and percentage of granular } \\
\text { cells, } 81 \% \text { ) was obtained as compared with the } \\
\text { control }\left(104 \mathrm{mg} \mathrm{mL}^{-1}, 3,51 \% \text { respectively). }\right.\end{array}$ & Llario et al. (2020) \\
\hline Bacillus pumilus & $\begin{array}{l}\text { The probiotic was evaluated in a prawn culture } \\
\text { (Marsupenaeus japonicus) at doses of } 1 \times 10^{7}, 1 \times 10^{8} \text {, } \\
\text { and } 1 \times 10^{9} \mathrm{CFU} \mathrm{g}^{-1} \text {. The immune response was } \\
\text { stimulated, as the activity of catalase, nitric oxide } \\
\text { synthase, and acid phosphatase increased signifi- } \\
\text { cantly in probiotic treatments as compared with the } \\
\text { control. }\end{array}$ & Zhao et al. (2019) \\
\hline Commercial probiotics & $\begin{array}{l}\text { Supplementation with a commercial probiotic } \\
\text { enhanced the prawns' immune activity (Macrobra- } \\
\text { chium rosenbergii); the hematological profile } \\
\text { reflected the effect of the probiotic. }\end{array}$ & Jakhar et al. (2016) \\
\hline $\begin{array}{l}\text { Bacillus subtilis and } \\
\text { Lactobacillus sp. }\end{array}$ & $\begin{array}{l}M \text {. rosembergii grown in biofloc significantly } \\
\text { increased }(P<0.05) \text { the number of hemocytes, } \\
\text { phagocytes, serum superoxide dismutase, and } \\
\text { lysozyme activity, when adding a mixture of the two } \\
\text { probiotics due to the increase }(P<0.05) \text { of the two } \\
\text { probiotics in both the culture water and the intestine. }\end{array}$ & Miao et al. (2017) \\
\hline
\end{tabular}

Table 4. Results of the different probiotic concentrations used in prawn (Macrobrachium rosenbergii).

\begin{tabular}{|c|c|c|c|}
\hline Probiotic & Concentrations & Results & Author \\
\hline $\begin{array}{l}\text { Lactobacillus } \\
\text { plantarum }\end{array}$ & $\begin{array}{l}1 \times 10^{7}, 1 \times 10^{8} \text { and } \\
1 \times 10^{9} \mathrm{CFU} \mathrm{L}^{-1}\end{array}$ & $\begin{array}{l}\text { Prawns from the three probiotic doses had } \\
\text { significantly better growth, feeding efficiency, } \\
\text { biochemical composition, and immune response } \\
\text { compared to the control. }\end{array}$ & Dash et al. (2016) \\
\hline $\begin{array}{l}\text { Bacillus } \\
\text { subtilis }\end{array}$ & $1 \times 10^{8}$ cells $\mathrm{mL}^{-1}$ & $\begin{array}{l}\text { The probiotic had a significant effect on larval } \\
\text { growth. Survival was significantly higher in the } \\
\text { probiotic group }(55.3 \pm 1.02) \text { than in the control } \\
\text { group }(36.2 \pm 5.02) \text {. }\end{array}$ & Keysami et al. (2007) \\
\hline $\begin{array}{l}\text { Bacillus } \\
\text { licheniformis }\end{array}$ & $1 \times 10^{9} \mathrm{CFU} \mathrm{g}^{-1}$ & $\begin{array}{l}\text { The highest growth and best immune response were } \\
\text { registered with the highest bacterial density. In the } \\
\text { intestine, microbial counts in the presence of } B \text {. } \\
\text { licheniformis were significantly }(P<0.05) \text { higher in } \\
\text { the groups with probiotics that were in control. }\end{array}$ & Kumar et al. (2013) \\
\hline
\end{tabular}

physiology, and water quality, specifically of the species in question: fish, mollusks, or crustaceans (Villamil \& Martínez, 2009).

\section{ACKNOWLEDGMENTS}

The first author acknowledges the Graduate Studies program in Ciencias Biológicas y de la Salud, de la Universidad Autónoma Metropolitana, Xochimilco, for 
the support granted and to the Consejo Nacional de Ciencia y Tecnología (CONACYT) for having awarded the scholarship (\# CVU 763372) to successfully conclude the curriculum in the allotted time.

\section{REFERENCES}

Ahmad, I., Rani, A.B., Verma, A.K. \& Maqsood, M. 2017. Biofloc technology: an emerging avenue in aquatic animal healthcare and nutrition. Aquaculture International, 25(3): 1215-1226.

Ajadi, A., Sabri, M.Y., Atata, J.A., Daodu, O.B. \& Emikpe, B.O. 2019. Pathology and immunohistochemical evaluation of Vibrio alginolyticus infection in Macrobrachium rosenbergii. Comparative Clinical Pathology, 28(2): 359-368.

Akter, R., Motiur, M.R., Rakibul, I.H.M., Islam, S. \& Uddin, A. 2017. Role of different types of probiotics in the pond ecosystem in prawn (Macrobrachium rosenbergii) health and production. International Journal of Fisheries and Aquatic Studies, 5(3): 83-87.

Albertoni, E., Palma, C. \& Esteves, F. 2003. Overlap of dietary niche and selectivity of three shrimp species (Crustacea, Decapoda) in a tropical coastal lagoon (Rio de Janeiro, Brazil). Revista Brasileira de Zoologia, 20(1): 395-403.

Asaduzzaman, M., Rahman, M.M., Azim, M.E., Islam, M.A., Wahab, M.A., Verdegem, M.C.J. \& Verreth, J.A.J. 2010. Effects of C/N ratio and substrate addition on natural food communities in freshwater prawn monoculture ponds. Aquaculture, 306(1-4): 127-136.

Avnimelech, Y. 2012. Biofloc technology. A practical guidebook. The World Aquaculture Society, Baton Rouge.

Azad, M.A.K., Islam, S.S., Sithi, I.N., Ghosh, A.K., Banu, G.R., Bir, J. \& Huq, K.A. 2019. Effect of probiotics on immune competence of giant freshwater prawn Macrobrachium rosenbergii. Aquaculture Research, 50(2): 644-657.

Azim, M.E. \& Little, D.C. 2008. The biofloc technology (BFT) in indoor tanks: water quality, biofloc composition, and growth and welfare of Nile tilapia (Oreochromis niloticus). Aquaculture, 283(1-4): 2935.

Balcázar, J.L., De Blas, I., Ruiz-Zarzuela, I., Cunningham, D., Vendrell, D. \& Muzquiz, J.L. 2006. The role of probiotics in aquaculture. Veterinary Microbiology, 114(3-4): 173-186.

Ballester, E.L.C., Marzarotto, S.A., Silva de Castro, C., Frozza, A., Pastore, I. \& Abreu, P.C. 2017. Productive performance of juvenile freshwater prawns Macrobrachium rosenbergii in biofloc system. Aquaculture Research, 48(9): 4748-4755.
Bartelme, R.P., McLellan, S.L. \& Newton, R.J. 2017. Freshwater recirculating aquaculture system operations drive biofilter bacterial community shifts around a stable nitrifying consortium of ammonia-oxidizing archaea and comammox Nitrospira. Frontiers in Microbiology, 8: 101.

Bartie, K.L., Huys, G., Swings, J., Oanh, D.T.H., Phuong, N.T., Shariff, M. \& Giacomini, M. 2005. The Asiaresist Project: a study of antimicrobial resistance associated with Asian aqua-cultural environments. Workshop on Antibiotic Resistance in Asian Aquaculture Environments, 24-25 February 2005 Chiang Mai, Thailand.

Bauer, R. 2011. Amphidromy and migrations of freshwater shrimps. I. Costs, benefits evolutionary origins and an unusual case of amphidromy. In: Asakura, A. (Ed.). New frontiers in crustacean biology. Proceedings of the Crustacean Society Summer Meeting, Tokyo, 20-24 September 2009, Brill, Leiden, pp. 145-156.

Becerra, M.J., Martínez, L.R., Martínez, M., Hernández, J., López, J.A. \& Mendoza, F. 2014. Effect of using autotrophic and heterotrophic microbial-basedsystems for the pre-grown of Litopenaeus vannamei, on the production performance and selected haemolymph parameters. Aquaculture Research, 5(45): 944-948.

Bentzon, T.M., Sonnenschein, E.C. \& Gram, L. 2016. Monitoring and managing microbes in aquaculturetowards a sustainable industry. Microbial Biotechnology, 9(5): 576-584.

Borja, A. 2002. Los impactos ambientales de la acuicultura y la sostenibilidad de esta actividad. Boletín Instituto Español de Oceanografía, 18(1-4): 41-49.

Buschmann, A. 2007. Impacto ambiental de la acuicultura el estado de la investigación en Chile y el mundo. Terram, Santiago.

Cardona, E., Gueguen, Y., Magré, K., Lorgeoux, B., Piquemal, D., Pierrat, F. \& Saulnier, D. 2016. Bacterial community characterization of water and intestine of the shrimp Litopenaeus stylirostris in a biofloc system. BMC Microbiology, 16(1): 2-9.

Chen, C.Y., Chen, P.C., Weng, F.C.H., Shaw, G.T.W. \& Wang, D. 2017. Habitat and indigenous gut microbes contribute to the plasticity of gut microbiome in oriental river prawn during rapid environmental change. Plos One, 12(7): 1-20.

Cienfuegos, M.K., Monroy, D.M.C., Hamdan, P.A., Castro, M.J. \& Becerril, C.D. 2017. Probiotics used in biofloc system for fish and crustacean culture: a review. International Journal of Fisheries and Aquatic Studies, 5(5): 120-125. 
Crab, R., Defoirdt, T., Peter, B. \& Verstraete, W. 2012. Biofloc technology in aquaculture: beneficial effects and future challenges. Aquaculture, 356: 351-356.

Crab, R., Kochva, M., Verstraete, W. \& Avnimelech, Y. 2009. Bio-flocs technology application in overwintering of tilapia. Aquaculture Engineering, 40: 105-112.

Crab, R., Lambert, A., Defoirdt, T., Bossier, P. \& Verstraete, W. 2010. The application of bioflocs technology to protect brine shrimp (Artemia franciscana) from pathogenic Vibrio harveyi. Journal Applied Microbiology, 109(5): 1643-1649.

Das, S., Mondal, K. \& Haque, S. 2017. A review on application of probiotic, prebiotic, and symbiotic for sustainable development of aquaculture. Journal of Entomology and Zoology Studies, 5(2): 422-429.

Dash, G., Raman, R.P., Prasad, K.P., Marappan, M., Pradeep, M.A. \& Sen, S. 2016. Evaluation of Lactobacillus plantarum as a water additive on hostassociated microflora, growth, feed efficiency, and immune response of giant freshwater prawn, Macrobrachium rosenbergii (de Man, 1879). Aquaculture Research, 47(3): 804-818.

De Schryver, P., Crab, R., Defoirdt, T., Boon, N. \& Verstraete, W. 2008. The basics of bio-flocs technology: the added value for aquaculture. Aquaculture, 277(3-4): 125-137.

Deng, M., Chen, J., Gou, J., Hou, J., Li, D. \& He, X. 2018. The effect of different carbon sources on water quality, microbial community, and structure of biofloc systems. Aquaculture, 482: 103-110.

Díaz, R.G. \& Wacher, R.C. 2003. Métodos para el estudio de comunidades microbianas en alimentos fermentados. Revista Latina de Microbiología, 45(1-2): 3040.

Emerenciano, M., Gaxiola, G. \& Cuzon, G. 2013. Biofloc technology (BFT): a review for aquaculture application and animal food industry. In: Matovic, M.D. (Ed.). Biomass now-cultivation and utilization. InTech Open, London, pp. 301-328.

Emerenciano, M., Ballester, E., Cavalli, R. \& Wasielesky, W. 2011. Effect of biofloc technology (BFT) on the early postlarval stage of pink shrimp Farfantepenaeus paulensis: growth performance, floc composition, and salinity stress tolerance. Aquaculture International, 19(5): 891-901.

Emerenciano, M.G.C., Martínez-Córdova, L.R., MartínezPorchas, M. \& Miranda-Baeza, A. 2017. Biofloc technology (BFT): a tool for water quality management in aquaculture, water quality. InTech Open, London, pp. 91-109.

Ferreira, G.S., Bolivar, N.C., Pereira, S.A., Guertler, C., do Nascimento, V.F. \& Mouriño, J.L.P. 2015. Microbial biofloc as source of probiotic bacteria for the culture of Litopenaeus vannamei. Aquaculture, 448: 273-279.

García-Guerrero, M.U., Becerril-Morales, F., VegaVillasante, F. \& Espinosa-Chaurand, L.D. 2013. Los langostinos del género Macrobrachium con importancia económica y pesquera en América Latina: conocimiento actual, rol ecológico y conservación. Latin American Journal of Aquatic Research, 41(4): 651-675.

Ghosh, A.K., Bir, J., Azad, M.A.K., Hasanuzzaman, A.F.M., Islam, M.S. \& Huq, K.A. 2016. Impact of commercial probiotics application on growth and production of giant freshwater prawn (Macrobrachium rosenbergii De Man, 1879). Aquaculture Reports, 4: 112-117.

Grealis, E., Hynes, S., O'Donoghue, C., Vega, A., Van Osch, S. \& Twomey, C. 2017. The economic impact of aquaculture expansion: an input-output approach. Marine Policy, 81: 29-36.

Guo, F., Zhang, S.H., Yu, X. \& Wei, B. 2011. Variations of both bacterial community and extracellular polymers: the inducements of increase of cell hydrophobicity from biofloc to aerobic granule sludge. Bioresource Technology, 102(11): 6421-6428.

Gupta, A. \& Dhawan, A. 2011. Effect of supplementing probiotics (Prosol) on the performance of giant freshwater prawn (Macrobrachium rosenbergii) juveniles. Indian Journal of Animal Nutrition, 28(4): 457-463.

Gutiérrez, L.A. 2013. Probiotics: an alternative for cleaner production and a possible replacement of the antibiotics as growth promoters in animal feeding. Producción + Limpia, 8(1): 135-146.

Hargreaves, J.A. 2013. Biofloc production systems for aquaculture. SRAC, 4503: 8-10.

Irianto, A. \& Austin, B. 2002. Probiotics in aquaculture. Journal of Fish Diseases, 25(11): 633-642.

Jakhar, V., Sihag, R.C. \& Gahlawat, S.K. 2016. Effect of probiotics on the immunological status of giant freshwater prawn (Macrobrachium rosenbergii de Man). Indian Journal of Animal Research, 50(6): 930935.

John, G., Mohamed, R.R., Kolanchinathan, P. \& Balasundaram, A. 2018. Nutritional value of two bacterial strains Bacillus subtilis RCMB21 and Pseudomonas fluorescens RCMB39 as feed supplement for freshwater prawn Macrobrachium malcolmsonii. Asian Journal of Animal and Veterinary Advances, 13: 282-294.

Kathleen, M.M., Samuel, L., Felecia, C., Reagan, E.L., Kasing, A., Lesley, M. \& Toh, S.C. 2016. Antibiotic resistance of diverse bacteria from aquaculture in Borneo. International Journal of Microbiology, 2016: 2164761. 
Keysami, M.R. Saad, K. Sijam, H.D. \& Alimon, A. 2007. Effect of Bacillus subtilus on growth, development, and survival of larvae of Macrobrachium rosenbergii (de Man). Aquaculture Nutrition, 13(2): 131-136.

Kumar, N.R., Raman, R.P., Jadhao, S.B., Brahmchari, R.K., Kumar, K. \& Dash, G. 2013. Effect of dietary supplementation of Bacillus licheniformis on gut microbiota, growth, and immune response in giant freshwater prawn, Macrobrachium rosenbergii (de Man, 1879). Aquaculture International, 21(2): 387403.

Llario, F., Romano, L.A., Rodilla, M., Sebastiá-Frasquet, M.T. \& Poersch, L.H. 2020. Application of Bacillus amyloliquefaciens as probiotic for Litopenaeus vannamei (Boone, 1931) cultivated in a biofloc system. Iranian Journal of Fisheries Sciences, 19(2): 904-920.

Luis-Villaseñor, I.E., Voltolina, D., Audelo-Naranjo, J.M., Pacheco-Marges, M.R., Herrera-Espericueta, V.E. \& Romero-Beltrán, E. 2015. Effects of biofloc promotion on water quality, growth, biomass yield, and heterotrophic community in Litopenaeus vannamei (Boone, 1931) experimental intensive culture. Italian Journal of Animal Science, 14(3): 332-337.

Martínez-Cruz, P., Ibáñez, A.L., Monroy-Hermosillo, O.A. \& Ramírez-Saad, H.C. 2012. Use of probiotics in aquaculture. ISRN Microbiology, 2012: 1-13.

Martins, P., Cleary, D.F., Pires, A.C., Rodrigues, A.M., Quintino, V., Calado, R. \& Gomes, N.C. 2013. Molecular analysis of bacterial communities and detection of potential pathogens in a recirculating aquaculture system for Scophthalmus maximus and Solea senegalensis. Plos One, 8(11): 1-17.

Maya, S.G., Monroy, D.M.C., Hamdan, A.P., Castro, J.M., Rodríguez, G.A. \& de Oca, M. 2016. Effect of two carbon sources in microbial abundance in a biofloc culture system with Oreochromis niloticus (Linnaeus, 1758). International Journal of Fisheries and Aquatic Studies, 4(3): 421-427.

McDowall, R. 2007. On amphidromy, a distinct form of diadromy in aquatic organisms. Fish and Fisheries, 8(1): 1-13.

Miao, S., Zhu, J., Zhao, C., Sun, L., Zhang, X. \& Chen, G. 2017. Effects of $\mathrm{C} / \mathrm{N}$ ratio control combined with probiotics on the immune response, disease resistance, intestinal microbiota, and morphology of giant freshwater prawn (Macrobrachium rosenbergii). Aquaculture, 476: 125-133.

Monroy, M.C., Rodríguez, G., Castro, J. \& Becerril, D. 2015. Importance and function of microbial communities in aquaculture systems with no water exchange. Scientific Journal of Animal Science, 4(9): 103-110.

Mujeeb, R.K.M., Jesmi, Y., Hatha, M.A.A. \& Thomas, A.P. 2017. Bacterial diversity of giant freshwater prawn, Macrobrachium rosenbergii and screening for probiotic potential bacteria. Journal of Aquaculture and Marine Science, 1(1): 2-8.

Murphy, N. \& Austin, C. 2005. Phylogenetic relationships of the globally distributed freshwater prawn genus Macrobrachium (Crustacea: Decapoda: Palaemonidae): biogeography, taxonomy, and the convergent evolution of abbreviated larval development. Zoologica Scripta, 34(2): 187-197.

Ndi, O.L. \& Barton, M.D. 2012. Resistance determinants of Pseudomonas species from aquaculture in Australia. Journal of Aquaculture Research \& Development, 3(1): 1-6.

Pandiyan, P., Balaraman, D., Thirunavukkarasu, R., George, E., Subaramaniyan, K., Manikkam, S. \& Sadayappan, B. 2013. Probiotics in aquaculture. Drug Invention Today, 5(1): 55-59.

Pérez-Fuentes, J.A., Hernández-Vergara, M.P., PérezRostro, C.I. \& Fogel, I. 2016. C:N ratios affect nitrogen removal and production of Nile tilapia Oreochromis niloticus raised in a biofloc system under high-density cultivation. Aquaculture, 452: 247-251.

Pileggi, L.G. \& Mantelatto, F.L. 2010. Molecular phylogeny of the freshwater prawn genus Macrobrachium (Decapoda, Palaemonidae), with emphasis on the relationships among selected American species. Invertebrate Systematics, 24(2): 194-208.

Poleo, G., Aranbarrio, J.V., Mendoza, L. \& Romero, O. 2011. Cultivo de cachama blanca en altas densidades $\mathrm{y}$ en dos sistemas cerrados. Pesquisa Agropecuaria Brasileira, 46(4): 429-437.

Prindle, A., Samayoa, P., Razinkov, I., Danino, T., Tsimring, L.S. \& Hasty, J. 2012. Sensing array of radically coupled genetic biopixels. Nature, 481(7379): 39-44.

Rubia, A.M., Rahman, M., Islam, H.R., Islam, S. \& Ahmed, K.K.U. 2017. Role of different types of probiotics in pond ecosystem in prawn (Macrobrachium rosenbergii) health and production. International Journal of Fisheries and Aquatic Studies, 5(3): 83-87.

Samocha, T.M., Patnaik, S., Speed, M., Ali, A.M., Burger, J.M., Almeida, R.V., Ayub, Z., Harisanto, M., Horowitz, A. \& Brock, D.L. 2007. Use of molasses as carbon source in limited discharge nursery and growout systems for Litopenaeus vannamei. Aquacultural Engineering, 36(2): 184-191.

Seenivasan, C., Bhavan, P.S. \& Radhakrishnan, S. 2011. Effect of probiotics (Binifit ${ }^{\mathrm{TM}}$ ) on survival, growth, biochemical constituents and energy budget of the freshwater prawn Macrobrachium rosenbergii postlarvae. Aquaculture, 41: 5919-5927. 
Seenivasan, C., Radhakrishnan, S., Muralisankar, T. \& Bhavan, P.S. 2016. Effects of probiotics on survival, growth and digestive enzymes activities in freshwater prawn Macrobrachium rosenbergii (De Man, 1879). Proceedings of the Zoological Society, 69(1): 52-60.

Suita, S.M., Ballester, E.L.C., Abreu, P.C. \& Wasielesky, W. 2015. Dextrose as carbon source in the culture of Litopenaeus vannamei (Boone, 1931) in a zeroexchange system. Latin American Journal of Aquatic Research, 43(3): 526-533.

Sumon, M.S., Ahmmed, F., Khushi, S.S., Ahmmed, M.K., Rouf, M.A., Chisty, M.A.H. \& Sarower, M.G. 2018. Growth performance, digestive enzyme activity, and immune response of Macrobrachium rosenbergii fed with probiotic Clostridium butyricum incorporated diets. Journal of King Saud University-Science, 30(1): 21-28.

Tzeng, T.D., Pao, Y.Y., Chen, P.C., Weng, F.C.H., Jean, W.D. \& Wang, D. 2015. Effects of host phylogeny and habitats on gut microbiomes of oriental river prawn (Macrobrachium nipponense). Plos One, 10(7): e0132 860.

Villamil, L. \& Martínez, M. 2009. Probióticos como herramienta biotecnológica en el cultivo de camarón: reseña. Boletín de Investigaciones Marinas y Costeras, 38: 165-187.

Received: 11 November 2019; Accepted: 23 May 2020
Wee, W.C., Mok, C.H., Romano, N., Ebrahimi, M. \& Natrah, I. 2018. Dietary supplementation use of Bacillus cereus as quorum sensing degrader and their effects on growth performance and response of Malaysian giant river prawn Macrobrachium rosenbergii juvenile towards Aeromonas hydrophila. Aquaculture Nutrition, 24(6): 1804-1812.

Wei, Y., Liao, S.A. \& Wang, A.L. 2016. The effect of different carbon sources on the nutritional composition, microbial community and structure of bioflocs. Aquaculture, 465: 88-93.

Yamashita, T., Emoto, T., Sasaki, N. \& Hirata, K.I. 2016. Gut microbiota and coronary artery disease. International Heart Journal, 57(6): 663-671.

Zhao, C., Zhu, J., Hu, J., Dong, X., Sun, L., Zhang, X. \& Miao, S. 2019. Effects of dietary Bacillus pumilus on growth performance, innate immunity and digestive enzymes of giant freshwater prawns (Macrobrachium rosenbergii). Aquaculture Nutrition, 25: 712-720.

Zhou, Q., Chen, T. \& Han, S. 2017. Characteristics of bacterial communities in cyanobacteria-blooming aquaculture wastewater influenced by the phytoremediation with water hyacinth. Water, 9(12): 1-11. 